\title{
Mekansime Komisi Pemberantasan Korupsi Dalam Proses Penyadapan Dilihat Dari Perspektif Hak Asasi Manusia
}

\author{
Oleh : Jennifer Ingelyne Nussy ${ }^{1}$; Harun Matayane ${ }^{2}$ \\ Email : jeannussy@gmail.com ${ }^{1}$; harunmatayane@gmail.com $^{2}$ \\ Ilmu Hukum, Fakultas Hukum, Universitas Pattimura
}

\begin{abstract}
Recognition and protection of a guarantee of human dignity to earn a respectable place in the eyes of the law and government. Related to the interests of law enforcement, the Corruption Eradication Commission (KPK) for the purpose of wiretapping evidence in court, while will protecting the privacyrights of suspects. Legal protections for the accused to be seen as matter of law adopted. Therefore, the protection of the privacy rights of a person to be seen in the investigation process. For the Commission to conduct wiretaps should see privacy rights as stipulated in the law and the government should establish a special set of rules that intercepts, thus providing the possibility for law enforcement has the authority to do so does not conflict with human rights.
\end{abstract}

Keywords : Tapping, Corruption Eradication Commission, Human Rights

\section{Pendahuluan}

Hukum adalah perangkat peraturanperaturan tertulis yang dibuat oleh pemerintah melalui badan-badan yang berwenang membuat berbagai peraturan tertulis seperti ; Undang-Undang Dasar, Undang-Undang, Keputusan Presiden, Keputusan Pemerintah, Keputusan Menteri dan Peraturan-Peraturan Daerah. ${ }^{1}$

Penjelasan Undang-Undang Dasar 1945 bahwa Negara Indonesia adalah negara hukum (Rechstaat) dan bukan negara kekuasaan (Machstaat). Hal ini berarti Negara Republik Indonesia sebagai negara

1 Soedjono Dirdjosisworo, Pengantar Ilmu Hukum, PT. Rajagrafindo, Jakarta, 2005, hal. 25 hukum yang demokratis dan menuntut aparat penegak hukum untuk selalu berusaha menjunjung tinggi hak asasi manusia dan menjamin segala warga negara bersamaan kedudukannya di dalam hukum dengan tidak ada kecualinya.

Pengakuan dan perlindungan Hak Asasi Manusia (HAM) yang dijadikan sebagai unsur utama negara Indonesia sebagai negara hukum merupakan jabaran dari konstitusi, bahwa negara ini berdasarkan atas hukum dan tidak berdasarkan atas kekuasaan belaka. Pengakuan dan perlindungan demikian merupakan jaminan kalau harkat dan martabat manusia memperoleh tempat yang terhormat di depan hukum dan pemerintah. 
Dalam posisi ini, manusia merupakan subjek yang mendapatkan jaminan perlindungan hak-hak kemanusiaan yang idealnya harus ditegakan. Oleh karena itu, berbicara tentang Hak Asasi atau hak yang mutlak sebagai seorang manusia dalam kaitannya dengan suatu negara yang menganut sistem negara hukum, maka hak asasi manusia dengan negara hukum tidak dapat dipisahkan, justru berpikir secara hukum berkaitan dengan ide bagaimana keadilan dan ketertiban itu dapat tewujud.

Secara konstitusi pengakuan terhadap Hak Asasi Manusia tertuang dalam Pasal 28 UUD NRI Tahun 1945. Perlindungan atas hak tersebut merupakan pelaksanaan dari Undang-Undang Dasar Republik Indonesia Tahun 1945 yakni pasal 28 huruf $\mathrm{G}$ ayat (1) yang menyatakan :

"Setiap orang berhak atas perlindungan diri pribadi, keluarga, kehormatan, martabat, dan harta benda yang di bawah kekuasaannya, serta berhak atas rasa aman dan perlindungan dari ancaman ketakutan untuk berbuat atau tidak berbuat sesuatu yang merupakan hak asasi."

Seiring waktu akhirnya pemerintah mengeluarkan Undang-Undang Nomor 39 Tahun 1999 tentang Hak Asasi Manusia. Dimana dalam Undang-Undang tersebut terdapat jaminan perlindungan hak asasi manusia, khususnya mengenai kemerdekaan dan rahasia dalam hubungan komunikasi, baik secara elektronik maupun nonelektronik, sebagaimana disebut dalam Pasal 32 Undang-Undang Hak Asasi Manusia, yang menyatakan :
"Kemerdekaan dan rahasia dalam hubungan surat-menyurat termasuk hubungan komunikasi melalui sarana elektronik tidak boleh diganggu, kecuali atas perintah hakim atau kekuasaan lain yang sah sesuai dengan ketentuan peraturan perundangundangan"

Selanjutnya dalam Undang-Undang Nomor 8 Tahun 1981 tentang Kitab Undang-Undang Hukum Acara Pidana (selanjutnya disingkat KUHAP) mengatur hukum acara pidana yang sudah memaparkan secara eksplisit di dalam Bab VI (Pasal 50 - Pasal 68) sesungguhnya untuk menghapus segala tindakan yang bertentangan dengan hak asasi manusia yang dilakukan oleh aparatur negara yang sebetulnya berkewajiban menjamin dan melindungi hak asasi manusia. Oleh karena itu, semangat yang dijunjung tinggi dalam pembentukan KUHAP adalah menjunjung tinggi harkat dan martabat manusia agar ditempatkan sebagai manusia utuh dengan segala kehormatan dan hak asasi yang melekat dalam diri setiap manusia. ${ }^{2}$

Perlindungan hak asasi manusia diberikan kepada warga Negara yang juga dalam proses peradilan pidana baik sebagai tersangka, terdakwa, terpidana dan atau korban, berkaitan dengan hal tersebut Mardjono Reksodiputro, mengatakan : "Fungsi dari suatu undang-undang acara pidana adalah untuk membatasi kekuasaan Negara dalam bertindak terhadap setiap

\footnotetext{
${ }^{2}$ Mujahid. A. Ratief, dkk., Laporan Tahunan 2007 Komisi Nasional RI, Jakarta, 2007, Hal. 68-69
} 
warga masyarakat yang terlihat dalam proses peradilan pidana". ${ }^{3}$

Kehadiran KUHAP sebagai pelaksana proses peradilan yang telah memberikan pedoman bagi penegak hukum dalam menjalankan proses peradilan. Dalam perkembangannya penyelidik dan penyidik diberikan kewenangan untuk melakukan penyadapan. Kewenangan untuk melakukan hal tersebut dibagi menjadi 2 (dua) bentuk, yaitu : (1) Kewenangan penyadapan untuk kepentingan penegakan hukum, dan (2) Kewenangan penyadapan untuk intelijen.

Kewenangan penyadapan untuk kepentingan penegakan hukum berbeda dengan kewenangan penyadapan untuk kepentingan intelijen, karena menurut Aloysius Wisnubroto dan Gregorius Widirtana : "Sekalipun di dalam tugas-tugas kepolisian fungsi intelijen merupakan bagian dari proses peyelidikan, namun sebagaimana diketahui bahwa proses intelijen dan proses hukum adalah berbeda. Proses intelijen didasarkan pada indikasi dan analisis, sedangkan proses hukum pada bukti dan fakta". ${ }^{4}$

Meskipun ada berbagai macam kewenangan yang diatur dalam perundangundangan di Indonesia yang diberikan kepada penyidik dan intelijen negara, dari semua perundang-undangan yang diberikan guna penyadapan untuk penegakan hukum

3 Mardjono Reksodiputro, Hak Asasi Manusia Dalam Sistem Peradilan Pidana Kumpulan Karangan Buku Ketiga, Jakarta : Pusat Pelayanan Keadilan Dan Pengabdian Hukum (d/h Lembaga Kriminologi) Universitas Indonesia, 1999, hal. 25

4 Al. Wisnuborto dan G. Widiarta, Pembaharuan Hukum Acara Pidana, Bandung, PT. Citra Aditya Bakti, 2005, hal. 26 dan penyadapan untuk kepentingan intelijen mekanismenya tidak diatur secara jelas, sehingga rawan disalahgunakan dan cenderung melanggar hak asasi manusia. Salah satu lembaga yang menjadi sorotan dalam melakukan penyadapan yakni Komisi Pemberantasan Korupsi sebagaimana diundangkan dalam Undang-Undang Nomor 30 Tahun 2002 pada Pasal 12a yang mengatur mengenai kewenangan penyadapan dari lembaga tersebut.

Perdebatan mengenai penyadapan lembaga menjadi polemik di Negara Indonesia, hal ini dikarenakan bahwa ada berbagai tumpang tindih kewenangan antar lembaga penegak hukum dalam melakukan proses penyadapan sebagaimana terlihat dalam beberapa Undang-Undang. Tetapi kewenangan Komisi Pemberantasan Korupsi dalam melakukan penyadapan jelas diatur dalam Undang-Undang. Hanya mekanismenya yang belum jelas, sehingga banyak lembaga penegak hukum lain seperti Kepolisian dan Kejaksaan maupun lembaga lain juga mempunyai kewenangan yang sama yang melakukan penyadapan. Hasil penyadapan yang dilakukan dalam perkara korupsi salah satunya. Undang-Undang intelijen juga mengatur kewenangan penyadapan. Sebagaimana diuraikan di atas, dimana hak asasi manusia merupakan suatu hal yang patut untuk dilihat sebab menyangkut privasi seseorang maka perlu diperjelas kepastian perundang-undangan terkait dengan mekansime penegak hukum dalam proses penyadapan. 


\section{Pembahasan}

\section{Peraturan Undang - Undang Tentang Proses Penyadapan}

Penyadapan merupakan kegiatan yang dilakukan untuk mendapatkan informasi secara tidak sah. Tidak sah karena informasi yang diperoleh tanpa sepengetahuan pengirim atau penerima pesan. Penyadapan banyak terjadi pada media telekomunikasi telepon. Namun, tidak menutup kemungkinan pada media yang lain, seperti telegraf, internet dan faksimili.

Menurut Black Law Dictionary, wiretapping diartikan sebagai berikut :Wiretapping, A from of electronic equesdropping, where, upon court order, enforcement officials surreptitiously, listen to phone calls ${ }^{5}$ T Terjemahan bebas penyadapan adalah suatu bentuk dari cara menguping secara elektronik, dimana berdasarkan perintah pengadilan yang dilakukan secara rahasia dan resmi, dengan mendengarkan pembicaraan melalui telepon. Kamus tersebut juga mencantumkan wiretapping memiliki persamaan istilah dengan "eaves dropping". Eaves dropping is knowingly and without lawful authority.

a) Entering into a private place intent to listen surreptitiously to private conversations or to observe the personal conduct of any other person or person therein or

5 Henry Campbell Black, M.A, 1996. Black's Law Dictionary With Promunciations, Abridged Fifth Editon, ST Paul, Minn, West Publishing Co, hal. 825 b) Installing or using outside a privat place any device for hearing, recording, amplifying, or broadcasting sounds originating in such place, which sounds would not ordinarity be audible or comprehensible outside, without the consent of the person or person entitled to privacy therein or

c) Installing or using any device or equipment for the interception of any telephone, telegraph, or other wire communication without the consent of the person in possession or control of the facilities for such wire communications such activities are regulated by state and federal statutes, and commonly require a court order

Eaves dropping adalah perbuatan yang dengan sengaja dan tanpa izin atau tanpa otoritas hukum (terjemahan bebas):

a) Masuk ke dalam wilayah privat seseorang untuk mendengar secara diam-diam pembicaraan yang pribadi atau untuk mengamati tingkah laku seseorang.

b) Memasang alat untuk mendengar pembicaraan pribadi untuk mendengar, merekam, mengeraskan atau menyiarkan suara asli di beberapa tempat dengan suara yang biasanya tidak akan kedengaran atau diselidiki dari luar, tanpa sepengathuan yang dipasang peralatan tersebut. 
c) Memasang peralatan untuk menyadap telepon, telegram atau jaringan komunikasi kabel tanpa izin dari seseorang atau tanpa izin yang berotoritas dari penyedia layanan jaringan komunikasi kabel sebagaimana diatur dalam undangundang dan peraturan pemerintah atau perintah pengadilan seperti biasanya.

Selain wiretapping, penyadapan juga menggunakan istilah lain yaitu :

Lawful interception. Lawful interception (LI) is a service that is legally authorized for monitoring or recording telephone calls in accordance with a court order or authorization of legal bodies. ${ }^{6}$

Dalam kamus, intercept diartikan sebagai menahan, menangkap, mencegat atau memintas. Sedangkan di dalam kamus Oxford didefinisikan sebagai to cut off from access or communication ${ }^{7}$. Di dalam Kamus Besar Bahasa Indonesia menyadap adalah mendengarkan (merekam) informasi

\footnotetext{
6 Monitoring Architecture for Lawful Interception in VoIP Networks. http:/hal.Archives.ouvertes.fr/docs/00/16/44/20/PDF/ Monitoring Architecture for Lawful Interception in VoIP Network.pdf. Diakses tanggal 21 Desember 2009

7 Intercept. The Free Dictionary, http://www.thefreedictionary.com/intercept. Diakses tanggal 21 Desember 2009
}

(rahasia, pembicaraan) orang lain dengan sengaja tanpa sepengetahuan orangnya. ${ }^{8}$

Pengertian lain dari Penyadapan secara sah yaitu Lawful Interception adalah suatu cara penyadapan dengan menempatkan posisi penyadap di dalam penyelenggara jaringan telekomunikasi sedemikian rupa sehingga penyadapan memenuhi syarat tertentu yang dianggap sah secara hukum. Syarat-syarat dalam hal ini diatur secara yuridis oleh negara yang bersangkutan, sehingga dimungkinkan terdapat perbedaan aturan serta standar antara suatu negara dengan negara lainnya. ${ }^{9}$

Selanjutnya menurut penjelasan Pasal 31 ayat (1) Undang-Undang Nomor 11 Tahun 2008 tentang Informasi dan Teknologi Elektronik disebutkan bahwa yang dimaksud dengan "intersepsi atau penyadapan" adalah :

kegiatan untuk mendengarkan, merekam, membelokkan, mengubah, menghambat, dan/atau mencatat transmisi Informasi Elektronik dan/atau Dokumen Elektronik yang tidak bersifat publik, baik menggunakan jaringan kabel komunikasi maupun jaringan nirkabel,

\footnotetext{
http://pusatbahasa.diknas.go.id/kbbi/index.php. Diakses tanggal 21 Desember 2019

9 Penyadapan Secara Sah untuk Telekomunikasi Bergerak Seluler (Lawful Interception for Cellular Telecommunication), http://www.rizaazmi.net. Diakses tanggal 21 Desember 2019
} 
seperti pancaran elektromagnetis atau radio frekuensi.

Jika ditinjau dari keberadaan aturan Lawful Interception di Indonesia, negara kita telah mengeluarkan Peraturan Menkominfo Nomor 11/PER/M.KOMINFO/02/2006 tentang Teknis Penyadapan Terhadap Informasi yang berisi pedomanpedoman dalam melakukan penyadapan secara sah. Dari definisi sesuai peraturan tersebut disebutkan bahwa Penyadapan Informasi adalah mendengarkan, mencatat, atau merekam suatu pembicaraan yang dilakukan oleh aparat penegak hukum dengan memasang alat atau perangkat tambahan pada jaringan telekomunikasi tanpa sepengetahuan orang yang melakukan pembicaraan atau komunikasi tersebut.

Di dalam Rapat Pimpinan (Rapim) Asosiasi Advokat Indonesia (AAI) pada tanggal 20-21 Juli 2006 lalu ada hal menarik yang dibahas dalam rapim tersebut yaitu soal advokat dan penyadapan. Dalam rapim tersebut mereka menuntut aparat penegak hukum menghormati Pasal 19 ayat (2) Undang - Undang No. 18/2003 tentang Advokad yang memberikan perlindungan kepada advokad dari tindakan penyitaan atau pemeriksaan terhadap berkas dan dokumen, serta perlindungan dari penyadapan sarana komunikasi elektronik. Pemerintah melalui Departemen Komunikasi dan Informasi saat ini tengah menyiapkan Rancangan Peraturan Pemerintah (RPP) mengenai tata cara penyadapan bagi penegakan hukum (atau disebut dengan RPP tentang Tata Cara Intersepsi). Pemerintah beralasan bahwa bahwa Rancangan ini merupakan amanat Undang-Undang No 11 Tahun 2008 tentang Informasi dan Transaksi Elektronik dan menertibkan kewenangan penyadapan karena sekarang patut dicurigai antarinstansi saling melakukan penyadapan. RPP ini ditargetkan selesai enam bulan ke depan.

Pengaturan penyadapan ini muncul ketika KPK sedang dilemahkan dan dikriminalisasi. Padahal KPK dinilai relative lebih berhasil menuntaskan kasus korupsi yang melibatkan banyak aktor yang berasal dari kalangan eksekutif, legislative, yudikatif dan swasta. Prestasi ini tentu tidak bias dilepaskan dari kewenangan luar biasa yang dimilikinya, khususnya "melakukan penyadapan dan merekam pembicaraan mulai dari tahapan penyelidikan, penyidikan dan penuntutan" (Pasal 12 ayat (1) huruf a). Dengan kewenangan penyadapan tersebut, terbukti sejumlah koruptor berhasil dijerat dan tertangkap tangan oleh KPK.

Kesimpangsiuran pengaturan tentang penyadapan di Indonesia Nampak dari banyaknya ketentuan perundang-undangan yang memberikan kewenangan kepada institusi negara untuk melakukan tindakan penyadapan, dengan batasan yang seringkali berlainan, antara satu ketentuan dengan ketentuan lainnya.

Deretan pengaturan mengenai penyadapan setidaknya dapat dijumpai dalam sejumlah ketentuan perundangundangan berikut ini : 
a. Bab XXVII KUHP Tentang Kejahatan Jabatan, Pasal 430 sampai dengan Pasal 434.

b. Undang-Undang Nomor 5 Tahun 1997 tentang Psikotropika.

c. Undang-Undang Nomor 31 Tahun 1999 tentang Pemberantasan Tindak Pidana Korupsi.

d. Undang-Undang Nomor 36 Tahun 1999 tentang Telekomunikasi.

e. Perpu Nomor 1 Tahun 2002 tentang Pemberantasan Tindak Pidana Terorisme.

f. Undang-Undang Nomor 30 Tahun 2002 tentang Komisi Pemberantasan Tindak Pidana Korupsi.

g. Undang-Undang Nomor 18 Tahun 2003 tentang Advokad

h. Undang-Undang Nomor 21 Tahun 2007 tentang Pemberantasan Tindak Pidana Perdagangan Orang.

i. Undang-Undang Nomor 11 Tahun 2008 tentang Informasi dan Transaksi Elektronik.

j. Undang-Undang Nomor 35 Tahun 2009 tentang Narkotika.

k. Undang-Undang Nomor 17 Tahun 2011 tentang Intelijen Negara.

1. Undang-Undang Nomor 18 Tahun 2011 tentang Perubahan UndangUndang Nomor 18 Tahun 2004 tentang Komisi Yudisial.

m. Peraturan Pemerintah Nomor 19 Tahun 2000 tentang Tim Gabungan Pemberantasan Tindak Pidana Korupsi.

n. Peraturan Pemerintah Nomor 52 Tahun 2000 tentang Penyelenggaraan Telekomunikasi.

o. Peraturan Menteri Informasi dan Komunikasi Nomor 11 Tahun 2006 tentang Teknis Penyadapan Terhadap Informasi. p. Peraturan Menteri Informasi dan Komunikasi Nomor 1 Tahun 2008 tentang Perekaman Informasi untuk Perubahan dan Keamanan Negara.

Dengan ketiadaan aturan tunggal tentang hukum acara dan/atau tata cara penyadapan di Indonesia telah menjadikan masyarakat Indonesia adalah masyarakat yang paling terancam ha katas privasinya, diantara masyarakat lain di negara-negara hukum modern yang demokratis di dunia. Situasi ini dimungkinkan, karena aparat negara bias dengan mudah menggunakan berbagai macam cara untuk melakukan intervensi terhadap hak privasi warganya.

Di Indonesia kesemrawutan hukum penyadapan terlihat dengan banyaknya otoritas yang memberikan izin untuk penyadapan. Marilah kita lihat siapa saja yang memiliki otoritas tersebut dalam regulasi Indonesia, UU Psikotropika membolehkan penyadapan telepon dan perekaman pembicaraan dengan izin kepala Polri. Undang-Undang Narkotika (UndangUndang Nomor 35 Tahun 2009) membolehkan Badan Narkotika Nasional (BNN) melakukan penyadapan dengan izin ketua Pengadilan Negeri, namun dalam kondisi yang mendesak dapat pula dilakukan penyadapan tanpa izin.

Adapun pengertian dari penyadapan seperti yang tercantum di dalam penjelasan Pasal 32 UU Intelejen Negara disebutkan bahwa :

$\begin{array}{lr}\text { "Yang dimaksud } & \text { dengan } \\ \text { "penyadapan" adalah } & \text { kegiatan } \\ \text { mendengarkan, } & \text { merekam, } \\ \text { membelokkan, } & \text { mengubah, }\end{array}$


menghambat, dan/atau mencatat transmisi informasi elektronik dan/atau dokumen elektronik, baik menggunakan jaringan kabel komunikasi maupun jaringan nirkabel, seperti pancaran elektromagnetik atau radio frekuensi termasuk memeriksa paket, pos, surat-menyurat, dan dokumen lain."

Pernyataan di atas menunjukkan bahwa otoritas yang mengizinkan dilakukannya penyadapan di Indonesia sangat beragam dan berbeda-beda tergantung sasarannya. Padahal umumnya di negara lain, izin peyadapan hanya dimiliki oleh satu otoritas saja. Ada yang menggunakan model yang izinnya diberikan oleh pemerintah (executive authorization) ada yang menggunakan model yang izinnya diperoleh dari pengadilan (judicial authorization), dan model yang diizinkan oleh hakim komisaris (investigating magistrate). Indonesia justru menganutnya secara campur sari, tanpa adanya mekanisme control yang pasti.

\section{Mekanisme KPK Dalam Proses Penyadapan Dari Aspek Hak Asasi Manusia}

Argumentasi HAM seringkali diposisikan berseberangan dengan upaya serius pemberantasan korupsi. Pada satu titik, alasan HAM menjadi kontradiktif dengan upaya perlindungan hak kolektif (hak asasi publik). Pertentangan antara norma perlindungan hak asasi individual dengan hak asasi public seharusnya ditempatkan pada proporsi yang seimbang dan tidak dapat dilebihkan, diutamakan (diprioritaskan) satu dari yang lain.

Pasal 17 Konvensi Internasional tentang hak sipil dan politik Tahun 1966 memang mengatur bahwa tidak seorangpun dapat berbuat sewenang-wenang atau secara tidak sah mencampuri masalah pribadi, keluarga, rumah atau koresponden seseorang. Atas dasar inilah, sebagian pihak bersihkeras, penyadapan yang dikualifikasikan sebagai salah satu perluasan arti "korespondensi" menolak kewenangan penyadapan KPK.

Aturan yang sama terdapat pada Pasal 8 ayat (1), Konvensi Eropa untuk perlindungan HAM dan Kebebasan Fundamental (1958) menyatakan :

Setiap orang berhak atas penghormatan terhadap kehidupan pribadi atau keluarganya, rumah tangganya dan surat-menyurat".

Sepintas jika hanya dua pasal itu yang digunakan, penyadapan KPK terhadap sejumlah pihak yang diduga terkait kasus korupsi akan dinyatakan melanggar HAM. Namun, konvensi-konvensi Internasional dan bahkan konvensi Nasional Indonesia harus dibaca secara utuh. Sebab pada konvensi-konvensi tersebut dapat dikecualikan sepanjang sesuai dengan hukum nasional, diperlukan dalam suatu masyarakat demokrasi, demi kepentingan nasional (publik) dan demi menjaga hak-hak dan kebebasan orang yang lebih luas, bahkan UUD 1945 menegaskan pengecuali tersebut.

Perlindungan hukum bagi tersangka dalam proses peradilan tidak dapat dilepaskan dari apa yang sebenarnya tujuan 
atau dasar pemikiran dari peradilan tersangka itu sendiri bertolak dari dasar pemikiran baru yang dapat ditentukan apa dan bagaimana hakikat wujud dari perlindungan hukum yang sifatnya diberikan kepada tersangka. Tujuan dan dasar pemikiran dari peradilan tersangka jelas tidak dapat dilepaskan dari tujuan utama untuk mewujudkan kesejahteraan tersangka yang pada dasarnya merupakan bagian integral dari kesejahteraan sosial. Bahwasanya kesejahteraan atau kepentingan tersangka berada di bawah kepentingan masyarakat, tetapi justru harus dilihat bahwa mendahulukan atau mengutamakan kesejahteraan dan kepentingan tersangka itu pada hakikatnya merupakan bagian dari usaha mewujudkan kesejahteraan sosial. ${ }^{10}$

Banyaknya putusan pengadilan yang berkaitan erat dengan peradilan tersangka dalam usaha pencegahan dan penanggulangan terhadap tersangka. Terkait dengan hal ini, dimana ada sejumlah asumsi yang timbul dalam masyarakat mengenai kurangnya hak-hak tersangka dalam proses peradilan lewat pemeriksaan ditingkat penyidikan. Sebagaimana dijelaskan bahwa Undang-Undang Nomor 8 Tahun 1981 tentang KUHAP mengatur hak-hak tersangka secara terurai dalam Pasal 50 sampai Pasal 68.

Hak Asasi Manusia adalah hak-hak dasar atau hak-hak pokok yang dibawa manusia sejak lahir sebagai anugerah Tuhan

10 Muladi, Perkembangan Tindak Pidana Dalam KUHP Mendatang, Makalah disampaikan Dalam Rangka Penataran Nasional Hukum Pidana Dan Kriminlogi Untuk Dosen-Dosen PTN/PTS Se Indonesia 1992, hal. 11
Yang Maha Esa. Hak-hak ini menjadi dasar dari hak-hak dan kewajiban-kewajiban lain. ${ }^{11}$ Menurut Mahfud MD, Hak Asasi Manusia diartikan sebagai : hak yang melekat pada martabat manusia sebagai makhluk ciptaan Tuhan, dan hak tersebut dibawa manusia sejak lahir ke muka bumi sehingga hak tersebut bersifat fitri (kodrati), bukan merupakan pemberian manusia atau Negara. ${ }^{12}$

Untuk memahami hakikat Hak Asasi Manusia (HAM), terlebih dahulu akan dijelaskan pengertian dasar tentang hak. Secara definitif "hak" merupakan unsur normatif yang berfungsi sebagai pedoman berperilaku, melindungi kebebasan, kekebalan serta menjamin adanya peluang bagi manusia dalam menjaga harkat dan martabatnya. Hak mempunyai unsur-unsur sebagai berikut; Pemilik hak; Ruang lingkup penerapan hak; dan Pihak yang bersedia dalam penerapan hak. Ketiga hal tersebut menyatu dalam pengertian dasar tentang hak. Salah satu Ahli Filsafat Politik Hukum ternama John Locke mengemukakan bahwa Hak Asasi Manusia hak-hak yang diberikan langsung oleh Tuhan Yang Maha Pencipta sebagai hak yang kodrati. ${ }^{13}$

11 C. S. T. Kansil, Sekitar Hak Asasi Manusia Dewasa Ini, Djambatan, Jakarta, 2003, hal. 11

12 Mahfud, M.D. Moh., Dasar \& Struktur Ketatanegaraan Indonesia, Rineka Cipta, Jakarta, 2001, hal. 5

13 Masyur Effendi, Dimensi dan Dinamika Hak Asasi Manusia dalam Hukum Nasional dan Internasional. Ghalia Indonesia, Jakarta, 1994, hal. 3 
Dalam Undang-Undang (UU) Nomor 39 Tahun 1999 Tentang Hak Asasi Manusia Pasal 1 disebutkan bahwa :

"Hak Asasi Manusia (HAM) adalah seperangkat hak yang melekat pada hakikat dan keberadaan manusia sebagai makhluk Tuhan Yanpg Maha Esa dan merupakan anugerah-Nya yang wajib dihormati, dijunjung tinggi, dan dilindungi oleh Negara, hukum pemerintah dan setiap orang demi kehormatan serta perlindungan harkat dan martabat manusia".

Berdasarkan beberapa rumusan pengertian HAM di atas, diperoleh suatu kesimpulan bahwa HAM merupakan hak yang melekat pada diri manusia yang bersifat kodrati dan fundamental sebagai suatu anugerah Allah yang harus dihormati, dijaga dan dilindungi oleh setiap individu, masyarakat atau Negara. Dengan demikian hakikat penghormatan dan perlindungan terhadap HAM merupakan upaya menjaga keselamatan eksistensi manusia secara utuh melalui aksi keseimbangan yaitu keseimbangan antara hak dan kewajiban, serta keseimbangan antara kepentingan perseorangan dengan kepentingan umum. Begitu juga upaya menghormati, melindungi, dan menjunjung tinggi HAM, menjadi kewajiban dan tanggungjawab bersama antara individu, pemerintah (aparatur pemerintahan baik sipil maupun militer) dan Negara.

Berdasarkan beberapa rumusan HAM di atas, dapat ditarik kesimpulan tentang beberapa ciri pokok hakikat HAM yaitu : a. HAM tidak perlu diberikan, dibeli ataupun diwarisi. HAM adalah bagian dari manusia secara otomatis;

b. HAM berlaku untuk semua orang tanpa memandang jenis kelamin, ras, agama, etnis, pandangan politik atau asalusul sosial dan bangsa;

c. HAM tidak bias dilanggar. Tidak seorangpun mempunyai hak untuk membatasi atau melanggar hak orang lain. Orang tetap mempunyai HAM walaupun sebuah Negara membuat hukum yang tidak melindungi atau melanggar HAM. $^{14}$

Hak Asasi Manusia bermula dari sebuah gagasan. Gagasan yang dimaksudkan yaitu manusia tidak boleh diperlakukan semena-mena oleh kekuasaan. Mengapa demikian? Sebab manusia memiliki hak alamiah. Hak alamiah itu melekat begitu saja pada manusia. Ia bukan pemberiaan siapa-siapa. Manusia memilikinya karena kemanusiaannya, bukan karena etnis, ras, jenis kelamin atau agama. Dengan kata lain hak alamiah melekat pada manusia sebagai individu. Jadi Negara, komunitas atau kelompok tidak dapat membatasi hak-hak itu, tanpa persetujuan bebas dari individu. ${ }^{15}$

\footnotetext{
14 Mansour Fakih dkk., Menegakkan keadilan dan Kemanusiaan Pegangan Untuk Membangun Gerakan HAM, Insist Press, Yogyakarta, 2003, hal. 2

15 Ibid
} 
Setelah berbagai macam pengertian, pandangan, pendapat ataupun pemikiran terkait Hak Asasi Manusia yang telah dipaparkan dapat digambarkan bahwa mengenai HAM di Indonesia yaitu sebagai tatanan nilai, norma, konsep yang hidup di masyarakat dan acuan bertindak pada dasarnya telah berlangsung cukup lama. Secara garis besar Bagir Manan membagi perkembangan pemikiran HAM di Indonesia dalam dua periode yaitu periode sebelum kemerdekaan (1908-1945) dan periode setelah kemerdekaan (1945sekarang). ${ }^{16}$ Perlindungan hak asasi manusia (HAM) adalah salah satu pilar utama negara demokrasi, selain dari supremasi hukum yang dicerminkan oleh the rule of law. Sebagai suatu negara demokrasi yang berdasarkan atas hukum (rechtstaat), sudah selayaknya Indonesia mengatur perlindungan hak asasi manusia (HAM) tersebut dalam konstitusinya.

Berbicara mengenai mekanisme
sama halnya berbicara mengenai
penanganan. Penyadapan merupakan hal baru dalam hukum positif Indonesia sebagaimana diketahui bahwa penyadapan yang dimasukan dalam ketentuan undangundang melalui kewenangan memang secara substansial mempunyai suatu makna yang logis dalam mendukung lancarnya proses peradilan untuk mewujudkan penegakan hukum yang sebagaimana mestinya diharapkan oleh masyarakat.

16 Manan Bagir, Perkembangan Pemikiran dan Pengaturan HAM di Indonesia, Yayasan Hak Asasi Manusia, Demokrasi dan Supremasi Hukum, Bandung, 2001
Terkait dengan kewenangan yang dimiliki oleh lembaga pemberantasan korupsi dalam hal menangani tindak pidana korupsi sebagaimana disebutkan pada Pasal 12 mengenai penyadapan memang jelas, tetapi mekanisme kewenangan untuk mengatur penyadapan tidak di dalam UU KPK. Sampai dengan pembahasan UU penyadapan sendiripun hanyalah sebatas wacana Program Legislatif Nasional (Prolegnas) mengapa dinyatakan demikian? Karena hingga saat ini apa yang sudah dibahas hanya sebatas wacana belaka yang tidak kunjung diresmikan apalagi direalisasikan. Hal demikian yang membuat kekaburan hukum pada UU tersebut sehingga belum memberikan kejelasan pasti mengenai mekanisme untuk melakukan penyadapan melalui prosesnya.

\section{Penutup}

Komisi Pemberantasan Korupsi merupakan lembaga yang dibentuk untuk menangani korupsi. Salah satu kewenangan yang dimiliki lembaga ini yakni melakukan penyadapan hasil pembicaraan sebagaimana diatur dalam Pasal 12a ayat (1). Tetapi proses penyadapan ini berkaitan juga dengan hak asasi seseorang sebagaimana dalam Undang-Undang memberikan jaminan perlindungan dan pelaksanaan hak asasi manusia bagi setiap warga negara berdasarkan atas hukum (rechtstaat). Perlindungan hak asasi manusia (HAM) diberikan kepada semua orang, termasuk juga yang melakukan penyadapan dalam hal privasi seseorang. 
Untuk itu, Pemerintah harus menyusun suatu rancangan UU yang khusus tentang penyadapan disertai dengan mekansimenya yang baik dan benar agar dijadikan sebagai payung untuk memberikan kewenangan khusus kepada lembaga mana yang berhak melakukan penyadapan demi kepentingan penyelidikan dan penyidikan agar diwujudkan sistem peradilan pidana yang baik dan juga dalam prosesnya harus memperhatikan Hak Asasi setiap orang

\section{Daftar Pustaka}

Bagir, M. (2001). Perkembangan Pemikiran dan Pengaturan HAM di Indonesia, Yayasan Hak Asasi Manusia, Demokrasi dan Supremasi Hukum. Bandung.

Dirdjosisworo, S. (2005). Pengantar Ilmu Hukum. Jakarta: PT. Rajagrafindo.

M. F. (Yogyakarta). Menegakkan keadilan dan Kemanusiaan Pegangan Untuk Membangun Gerakan HAM. 2003: Insist Press.

Effendi, ,. M. (1994). Dimensi dan Dinamika Hak Asasi Manusia dalam Hukum Nasional dan Internasional. Jakarta: Ghalia Indonesia.

Mahfud, M. M. (2001). Dasar \& Struktur Ketatanegaraan Indonesia. Jakarta: Rineka Cipta.

Mujahid. A. Ratief, d. (2017). Laporan Tahunan 2007 Komisi Nasional RI. Jakarta.

Reksodipuro, M. (2007). Hak Asasi Manusia Dalam Sistem Peradilan Pidana. Jakarta: Pusat Pelayanan Keadilan dan Pengabdian Hukum Universitas Indonesia.

Widiarta, A. W. (2015). Pembaharuan Hukum Acara Pidana. Bandung: PT. Citra Aditya Bakti. 